\title{
The role of telomere binding molecules for normal and abnormal hematopoiesis
}

\author{
Kentaro Hosokawa ${ }^{1}\left[\right.$ [ $\cdot$ Fumio Arai ${ }^{1}$
}

Received: 2 March 2018 / Accepted: 12 March 2018 / Published online: 17 March 2018

(c) The Japanese Society of Hematology 2018

\begin{abstract}
In order to maintain the homeostasis of the hematopoietic system, hematopoietic stem cells (HSCs) need to be maintained while slowly dividing over their lifetime. However, repeated cell divisions lead to the gradual accumulation of DNA damage and ultimately impair HSC function. Since telomeres are particularly fragile when subjected to replication stress, cells have several defense machinery to protect telomeres. Moreover, HSCs must protect their genome against possible DNA damage, while maintaining telomere length. A group of proteins called the shelterin complex are deeply involved in this two-way role, and it is highly resistant to the replication stress to which HSCs are subjected. Most shelterin-deficient experimental models suffer acute cytotoxicity and severe phenotypes, as each shelterin component is essential for telomere protection. The Tin2 point mutant mice show a dyskeratosis congenita (DC) like phenotype, and the Tpp1 deletion impairs the hematopoietic system. POT1/Pot1a is highly expressed in HSCs and contributes to the maintenance of the HSC pool during in vitro culture. Here, we discuss the role of shelterin molecules in HSC regulation and review current understanding of how these are regulated in the maintenance of the HSC pool and the development of hematological disorders.
\end{abstract}

Keywords Shelterin $\cdot$ Hematopoietic stem cell $\cdot$ Dyskeratosis congenital $\cdot$ Pot $1 \cdot$ Extra-telomeric function

\section{Introduction}

To maintain long-term tissue homeostasis, it is indispensable to employ a system based on stem cells and to preserve the self-renewal activity and multi-lineage differentiation potential of these stem cells. Proper control of self-renewal ability in hematopoietic stem cells (HSCs) is essential for maintaining functional mature cell production over organismal lifetime. However, it has been reported that DNA damage gradually accumulates through repeated cell divisions over long periods of time, and, along with replicative stress, markedly impairs stem cell function (Fig. 1) [1-9]. Ex vivo expansion of HSCs is a major challenge in cellular therapy, made more difficult by the high sensitivity of HSCs to DNA damage. On the other hand, it has been reported that

Kentaro Hosokawa

kenrou_h@scr.med.kyushu-u.ac.jp

1 Department of Stem Cell Biology and Medicine, Graduate School of Medical Sciences, Kyushu University, 3-1-1 Maidashi, Higashi-ku, Fukuoka 812-8582, Japan the telomere end is a particularly fragile site in vertebrate chromosomal DNA, and it is highly sensitive to DNA damage. Telomeres consist of specific tandem repeats (5'-TTA GGG-3'), which are oxidation-sensitive G-rich regions [10]. The 3' single-stranded G-rich overhang can be exposed to the DNA damage machinery, followed by cell cycle arrest and apoptosis. Furthermore, aberrant repair pathways lead to genomic abnormality and instability [11-13]. Therefore, prevention of DNA damage response and mechanisms for telomere end protection are required for the maintenance of the hematopoietic system [14-19].

The shelterin complex is composed of six protein subunits, TRF1, TRF2, RAP1, TIN2, TPP1, and POT1; they bind to the telomeric DNA region and are linked to the maintenance and regulation of telomere length and terminal loop structure [20,21]. Shelterin is known to play an important role in protecting telomeres from signaling via ataxia telangiectasia-mutated (ATM) and ataxia telangiectasia and RAD3-related (ATR)-mediated DNA damage response (DDR) [22-26]. Here, we focus on the shelterin component proteins and describe the molecular mechanisms underlying maintenance of the self-renewal activity of hematopoiesis 
Fig. 1 The shelterin complex is a gatekeeper that prevents HSC loss through telomere protection. HSCs repeatedly divide for self-renewal and progenitor cell production over organismal lifetime. The telomere is elongated by telomerase, and its activity is regulated by shelterin molecules. It is also the role of the shelterin complex to inhibit DNA damage response (DDR) caused by replicative stress. Since accumulation of excessive DNA damage leads to cell death, stem cell aging, and hematological malignancies, proper protection by shelterin is indispensable for maintenance of the normal HSC pool

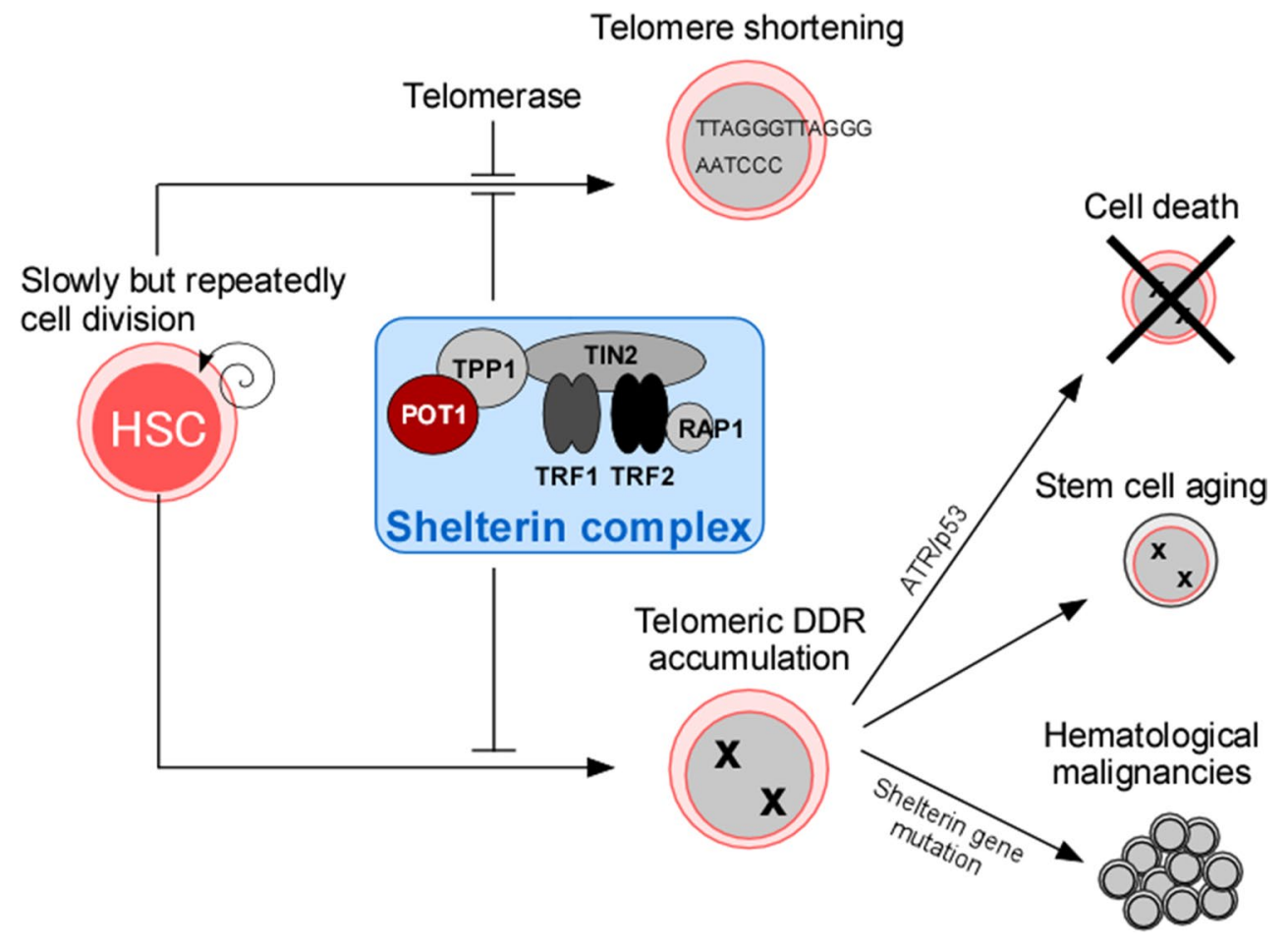

and controlling senescence and telomere dysfunction-associated disease.

\section{The role of shelterin proteins in telomere protection}

Several shelterin component proteins directly bind to telomeric DNA in maintaining telomere homeostasis. The Pot1/ Tpp1 heterodimer binds to telomeric single-stranded DNA (ssDNA), and Trf1/Trf2 binds to the double-stranded region [27-29]. The main role of $\operatorname{Trf1} 1 / \operatorname{Trf} 2$ in the telomere is the maintenance of the loop structure and the suppression of DDR. Trf1 controls telomere length negatively and promotes telomere duplication [30, 31]. It has been suggested that Trf1 separates from telomeres when phosphorylated by ATMdependent on the activity of the MRE11-RAD50-NBS1 complex, and this dissociation promotes telomere elongation by telomerase [32]. Therefore, appropriate activation of ATM is necessary for maintaining telomere homeostasis. On the other hand, Trf2 suppresses ATM signaling and downstream telomeric DNA resection [33], non-homologous end joining (NHEJ) and homology-directed repair (HDR) [34-36]. In mammals, the Trf2 interacting protein (Trf2ip), Rap1 forms a heterodimer with Trf2 and protects telomeres from inappropriate HDR pathway activation [37, 38]. Rap1 is the only shelterin molecule that inactivated mice do not result in embryonic lethality. The phenotype of Rap1 conditional knockout in epidermis shows telomere shortening, increased DNA damage, and skin hyperpigmentation [39]. In its canonical telomere-associate role, Tin2 is a central component of shelterin, contributing to the entry of the Tpp1/Pot1 heterodimer into the nucleus and tethering it to Trf1/Trf2 [22, 40, 41]. Tpp1, which is encoded by the gene $A c d$, forms a Pot1/Tpp1 heterodimer with Pot1, another shelterin member; this heterodimer caps telomeres by binding to the telomere G-rich overhang $[27,28]$. On the surface of the oligonucleotide/oligosaccharide binding fold domain (OB-fold) domain of the Tpp1, small clusters of amino acids called TEL patches are essential for both the recruitment of telomerase and promotion of telomere elongation activity [42-45]. Pot1 is a member of the shelterin complex, which binds to telomeric single-stranded DNA (ssDNA) G-rich overhangs via $\mathrm{N}$-terminal $\mathrm{OB}$-fold domains and caps telomeres to preserve genomic integrity $[46,47]$. POT1 cooperates with heterogeneous nuclear ribonucleoprotein A1 (hnRNPA1) and telomeric repeat-containing RNA (TERRA) to suppress aberrant DDR by inhibiting the binding of replication protein A (RPA) to ssDNA [48]. Although human shelterin contains a single POT1 gene, there are two Pot1 orthologs, Potla and Potlb in the mouse genome, which have different functions in telomeres [49-52]. Pot 1a is essential for suppressing cytogenetic abnormalities, which occur due to the activation of DDR in telomeres and the subsequent activation in NHEJ and HDR-dependent repair pathways [34, 49, 50, 53]. Deficiency of Pot 1a in mice leads to early embryonic lethality. On the other hand, Pot $1 b$ is involved in maintaining G-tail length through the regulation 
of the Apollo nuclease and Exo1, or DNA polymerase [51, 52]. Although, Pot $1 b$-deficient mice are viable and fertile, Potlb-deficient cells show long single-stranded telomeric overhangs and telomere shortening [49, 50, 54].

\section{Extra-telomeric function of shelterin proteins}

Recently, functions of shelterin molecules other than protecting and maintaining telomere called extra-telomeric function have been reported. TRF2 also has functions as a transcriptional regulator. In the tumor vasculature of human cancers, TRF2 transcriptionally activates PDGF receptor $\beta$ and increases angiogenesis [55]. Conversely, the Wilms' tumor suppressor WT1 and the Wnt/ $\beta$-catenin signaling pathway regulate the expression level of TRF2 [55, 56]. Rap1 activates the NF- $\kappa B$-mediated pathway through binding to IKK and also binds to the sub-telomeric region as a transcriptional repressor, thereby contributing to the regulation of metabolic programs, including fatty acid and glucose metabolism, and PPAR $\alpha$ signaling [57, 58]. Indeed, the absence of Rap 1 leads to the negative control of gene expression of metabolism and cell proliferation. Based on this change, Rap1 deficient mice show adult-onset obesity due to metabolic defects. This phenotype is related to glucose intolerance and insulin resistance. TIN2 is involved in metabolic regulation. TIN2 can also be located in mitochondria and negatively regulates energy production by suppressing oxidative phosphorylation [59]. TPP1-TIN2 binding inhibits the transition of TIN2 to mitochondria and promotes entry into the nucleus. Together, these findings suggest that changes in the abundance of shelterin protein affect cellular metabolic regulation. TIN2 Study shows the concept that observation of quantitative changes in shelterin protein is necessary to promote understanding of extra-telomeric functions in shelterin molecules.

\section{Role of shelterin genes in the maintenance of normal hematopoiesis}

Acute $\operatorname{Tr} f 1$ deficiency in mouse bone marrow hematopoietic cells leads to aplastic anemia and bone marrow failure syndrome (BMF) (Table 1) [18, 60, 61]. Interestingly, although this increases telomeric DDR and p53-p21-mediated cellular senescence in hematopoietic progenitor cells, telomere shortening does not occur. On the other hand, chronic $\operatorname{Tr} f 1$ inactivation leads to severe telomere shortening, similar to human dyskeratosis congenita (DC). HSC pools in Trf1deficient mice are depleted through aberrant cell cycle progression, leading to decreased bone marrow reconstitution ability. These effects underlie the pathogenic effects of
Trf1-mediated shelterin mutation in human DC, through loss of telomere protection, followed by the rapid depletion of HSPCs.

Tpp1/Acd deficiency in mice leads to embryonic or perinatal lethality, but analysis of embryonic hematopoiesis of mice which are homozygous for the spontaneously occurring hypomorphic Acd allele has revealed that Acd/Tpp1 is essential for embryonic development (Table 1) [16, 62, 63]. In the hypomorphic Acd mice, HSPCs show loss of cell cycle quiescence and G2/M arrest, resulting in loss of long-term bone marrow reconstitution ability. This phenotype is similar to that of HSPCs in the fetal liver of Acd (flox/flox); VavCre + mice, in which the HSPC pool is severely depleted. In adult hematopoiesis, as a result of conditional inactivation of $A c d$, acute chromosome instability, up-regulation of p53 target genes and G2/M arrest are observed. Moreover, HSPCs are immediately exhausted after Acd deletion. In the case of competitive bone marrow transplantation, $A c d$ deficient HSPCs do not support bone marrow repopulation activity. Interestingly, p53 deletion does not rescue Acd-deficient HSPC function. Thus, it is suggested that Acd/Tpp1 maintains the homeostasis of the hematopoietic system via p53-dependent or independent pathways.

Deletion of Pot $1 b$ results in the formation of a long G-rich overhang by nucleolytic processing of the $5^{\prime}$ end of the C-rich strand by Apollo and Exo1, with progressive loss of total telomere length [52, 54, 64]. It has been suggested that the extension of the overhang recruits RPA and results in activation of an ATR-p53-dependent checkpoint response that impairs HSC function. In Pot lb-deficient mice, several premature aging-related phenotypes appear by 15 months of age (Table 1) [54, 65]. The mice exhibit low reproductive ability with a reduction in testes size and increased numbers of apoptotic cells in the testes and intestine. In the peripheral blood, leucopenia, anemia, and thrombocytopenia are observed. In adult hematopoiesis, severe depletion of the HSPC component, loss of cell cycle quiescence and decreasing bone marrow reconstitution ability are observed. Increased DDR, chromosomal fusion, and apoptosis were observed in HSCs of 4-month-old mice, as telomere protection declined. Potlb deletion in the background of telomerase inactivation presents with a more severe phenotype, including bone marrow failure and premature death (Table 1) [17, 54, 64, 65]. In Potlb-telomerase-p53 multideficient mice, apoptosis and depletion of HSPCs were partially restored [65]. Moreover, the simultaneous loss of Pot $1 b$ and the cellular senescence marker $p 16$ (INK4a), which restricts stem cell function [66, 67], activates ATRdependent DDR, resulting in increased p53-p21-dependent cell cycle arrest and apoptosis in HSPCs [17]. In Pot1b-p53 double-deficient mice, activation of DDR-based ATR and subsequent p53-independent apoptosis increases, suggesting that p73 is involved in this cascade [68]. Therefore, the 
Table 1 Role of shelterin components in the maintenance of HSCs

\begin{tabular}{|c|c|c|c|c|}
\hline$\frac{\text { Gene Name }}{\text { Trf1 }}$ & $\begin{array}{l}\text { Experimental tool } \\
\operatorname{Trfl}(\text { flox/flox); Mx1-Cre+ }\end{array}$ & \multicolumn{2}{|c|}{ Implications in hematopoiesis } & $\begin{array}{l}\text { References } \\
{[60]}\end{array}$ \\
\hline & & Acute TRF1 deletion & $\begin{array}{l}\text { Pancytopenia and BMF } \\
\text { No telomere shortening } \\
\text { TIFs increased } \\
\text { Aplastic anemia } \\
\text { Cellular senescence via p21 in progenitor cells }\end{array}$ & $\begin{array}{l}{[60]} \\
{[18]} \\
{[61]}\end{array}$ \\
\hline & & Chronic TRF1 deletion & $\begin{array}{l}\text { Massive impaired overall survival because of BMF } \\
\text { Massive telomere shortening }\end{array}$ & \\
\hline & & $\operatorname{Trf}(-/-)$ HSC & $\begin{array}{l}\text { No apoptosis } \\
\text { p53 activation } \\
\text { Repopulation potential impaired } \\
\text { Cell cycle progression }\end{array}$ & \\
\hline \multirow[t]{6}{*}{ Tpp1(Acd) } & Acd hypomorphic mutant mice & & Embryonic or perinatal lethal & [16] \\
\hline & & Fetal liver HSCs & $\begin{array}{l}\text { Loss of cell cycle quiescence/G2/M arrest } \\
\text { Completely loss of long-term BM reconstitution activity }\end{array}$ & [63] \\
\hline & Acd (flox/-); Mx1-Cre+ & Adult HSPCs & $\begin{array}{l}\text { Deplete HSPCs } 5 \text { days after induction of Cre recombination } \\
\text { Do not support hematopoiesis in p53 independent manner after } \\
\text { competitive BMT } \\
\text { Increase cell death with p53-independent caspase-3/7 activa- } \\
\text { tion } \\
\text { No telomere shortening } \\
\text { Acute chromosomal instability }\end{array}$ & [16] \\
\hline & Acd (flox/-); Cre-ERT2+ & Adult HSPCs & $\begin{array}{l}\text { Severely depleted HSPCs } 5 \text { days after induction of Cre recom- } \\
\text { bination }\end{array}$ & [16] \\
\hline & Acd(flox/flox); Vav-Cre+ & & Embryonic lethal & [16] \\
\hline & & Fetal liver HSCs & Severely depleted HSPCs & \\
\hline \multirow[t]{11}{*}{ Pot1b } & $\operatorname{Pot} 1 b(\Delta / \Delta)$ & By 15 months-old & $\begin{array}{l}\text { Leucopenia, anemia and thrombocytopenia was appeared in } \\
\text { the peripheral blood } \\
\text { Premature aging of reproductive ability with reducing the size } \\
\text { of testes } \\
\text { Hyperpigmentation of paws } \\
\text { Increase apoptotic cells in testes and intestine }\end{array}$ & $\begin{array}{l}{[54]} \\
{[65]}\end{array}$ \\
\hline & & Adult HSPCs & $\begin{array}{l}\text { Loss of the HSPC population by } 15 \text { months-old } \\
\text { Loss of cell cycle quiescence } \\
\text { Increase DNA damage response, chromosomal fusions and } \\
\text { apoptosis in 4-month-old HSCs } \\
\text { Loss of BM reconstitution ability }\end{array}$ & \\
\hline & $\begin{array}{l}\operatorname{Pot} 1 b(\Delta / \Delta) ; m \operatorname{Terc}(+/-) \\
\operatorname{Pot} 1 b(\Delta / \Delta) ; m \operatorname{merc}(+/-)\end{array}$ & & $\begin{array}{l}\text { Dyskeratosis congenita (DC) like phenotype in BM, testes and } \\
\text { small intestine } \\
\text { Premature death } \\
\text { Reduce BM cells } \\
\text { Telomere shortening }\end{array}$ & [65] \\
\hline & & Adult HSPCs & loss of the HSPC population by 6 months-old & [65] \\
\hline & & $\mathrm{BM}$ cells & $\begin{array}{l}\text { Increase DNA damage response, chromosomal fusions and } \\
\text { apoptosis in p53 dependent manner }\end{array}$ & \\
\hline & $\operatorname{Pot} 1 b(\Delta / \Delta) ; m \operatorname{Terc}(-/-)$ & & $\begin{array}{l}\text { Embryonic or perinatal lethal } \\
\text { Increase telomeric DNA damage response, chromosomal } \\
\text { fusions and apoptosis } \\
\text { Reduce BM cells }\end{array}$ & [54] \\
\hline & & BM cells & Increase stromal adipose tissue & \\
\hline & $\operatorname{Pot} 1 b(\Delta / \Delta) ; p 16(-/-)$ & & $\begin{array}{l}\text { Premature death } \\
\text { Increase apoptotic cells in testes and small intestine }\end{array}$ & [17] \\
\hline & & Adult HSPCs & $\begin{array}{l}\text { Reduce BM reconstitution ability than } \operatorname{Pot} 1 b(\Delta / \Delta) \text { HSCs } \\
\text { Completely loss of HSPCs population by } 40-45 \text { weeks-old in } \\
\text { p } 21 \text { dependent manner } \\
\text { Increase telomeric DDR signaling than } \operatorname{Pot} 1 b(\Delta / \Delta) \text { HSCs in } \\
\text { p21 dependent manner }\end{array}$ & \\
\hline & & Hematopoietic cells & $\begin{array}{l}\text { Telomere shortening } \\
\text { Increase chromosomal fusions and apoptosis in p21 dependent } \\
\text { manner }\end{array}$ & \\
\hline & $\operatorname{Pot} 1 b(\Delta / \Delta) ; m \operatorname{Terc}(-/-) ; p 16(-/-)$ & & Premature death & [17] \\
\hline
\end{tabular}


Table 1 (continued)

\begin{tabular}{|c|c|c|c|c|}
\hline \multirow{2}{*}{$\frac{\text { Gene Name }}{\text { Pot1a }}$} & \multirow{2}{*}{$\frac{\text { Experimental tool }}{\text { Pot1a knockdown }}$} & \multicolumn{2}{|c|}{ Implications in hematopoiesis } & \multirow{2}{*}{$\begin{array}{l}\text { References } \\
{[14]}\end{array}$} \\
\hline & & Adult HSCs & $\begin{array}{l}\text { Increase telomeric DDR signaling and apoptosis } \\
\text { Loss of BM reconstitution ability }\end{array}$ & \\
\hline & Pot1a overexpression & Adult HSCs & $\begin{array}{l}\text { Preserve long-term BM reconstitution ability during in vitro } \\
\text { culture } \\
\text { Inhibit telomeric DDR signaling } \\
\text { Prevent the activation of mTOR signaling and mitochondrial } \\
\text { ROS production }\end{array}$ & [14] \\
\hline & MTM-mouse POT1a & Adult HSCs & $\begin{array}{l}\text { Preserve long-term BM reconstitution ability during in vitro } \\
\text { culture } \\
\text { Inhibit telomeric DDR signaling and apoptosis }\end{array}$ & [14] \\
\hline & MTM-human POT1 & Human UCB HSCs & $\begin{array}{l}\text { Preserve long-term BM reconstitution ability during in vitro } \\
\text { culture } \\
\text { Inhibit telomeric DDR signaling }\end{array}$ & [14] \\
\hline
\end{tabular}

function of Pot1b in HSPCs is to maintain telomere end stability and suppress p53-dependent and independent apoptosis.

\section{Pot1a/POT1 maintains HSC activity with age}

Recently, we demonstrated that the expression of Potla in HSCs is important for suppressing telomeric DDR and maintaining stem cell activity, which decreases with aging (Fig. 2) [14]. Knockdown of Pot1a increases telomeric DDR and reduces long-term bone marrow reconstitution activity (Table 1). Also, the balance in the supply of mature cells changed, as myeloid cells increased, and B cells decreased. Decreased expression levels of Pot1a in HSCs resulted in reduced cell proliferation and increased apoptosis. Similarly, overexpression of a dominant-negative Pot1a form lacking the OB-fold domain resulted in the reduction of the long-term repopulation capacity of HSCs. Pot1a binding to ssDNA via the OB-fold region contributed to telomere stability and maintenance of functional HSCs. In contrast, exogenous POT1a protein treatment suppressed the telomeric DDR and maintained the reconstitution activity of HSCs (Table 1, Fig. 2). Furthermore, the exogenous Pot1a treatment partially restored the reduced reconstitution ability of aged HSCs and normalized the differentiation of donor cells. Furthermore, we observed that exogenous POT1a protein treatment or overexpression of POT1a altered metabolism via mTOR signaling and oxidative phosphorylation in HSCs. Exogenous POT1 protein treatment can also be applied to human HSCs. The treatment of human umbilical cord blood-derived HSCs with exogenous human POT1 protein maintained human HSC activity in culture (Table 1). It has recently been reported that the POT1 can bind not only ssDNA, but also sub-telomeric and non-telomeric DNA through its OB-fold domain [69]. As extra-telomeric roles, POT1 may be involved in gene transcription, replication, and repair. Our findings may implicate POT1 in these functions, but further research is needed for the elucidation of detailed mechanisms.

The single deficiency of most shelterin genes leads to acute injury and severe phenotypes. However, in the study of aging, mouse models with such acute disorders may not strictly represent models of aging, as the phenotype resulting from physiological aging is milder [70]. Therefore, to further clarify the aging of HSPCs, it may be necessary to construct stepwise expression control models in vivo.

\section{Abnormalities in shelterin gene related to hematological malfunction}

It has recently been reported that expression deficiency and mutation of shelterin genes are one of the causes of hematological disease (Table 2). In maintaining the stability of telomeres, the amount of each shelterin protein is strictly controlled, and once the balance is lost, the fragility of telomeres may be unmasked, which may cause chromosomal abnormalities by unwarranted repair activity.

Abnormal expression of shelterin molecules is observed in various hematopoietic malignancies. Impaired expression of TRF1, TRF2, and RAP1 is detected in chronic myeloid leukemia (CML), acute lymphoblastic leukemia (ALL) and acute myeloid leukemia (AML) [71-76]. Also, abnormal expression of TIN2, ACD/TPP1, and POT1 is involved in chronic lymphocytic leukemia (CLL), aplastic anemia, and multiple myeloma [72, 77-80]. The attenuation of telomere maintenance is involved in the genetic syndrome dyskeratosis congenita (DC) and its severe form Hoyeraal-Hreidarsson (HH) syndrome [81, 82]. DC is a congenital hematopoietic deficiency syndrome characterized by bone marrow failure, abnormalities of the skin, nails and mucous membranes and premature hair graying and loss, and in most cases involves the shortening of telomeres. The genes responsible for DC are mostly involved in telomere control: $D K C 1$ (Dyskerin), NOP10, NHP2, TINF2 (encoding TIN2), TCAB1, TERC, 
Fig. 2 Maintenance of HSC activity by exogenous POT1a. In the steady state, HSCs slowly but repeatedly divide and selfrenew. With progressive aging, telomere DDR accumulation and $\mathrm{BM}$ reconstitution ability decrease in HSCs. Similar defects occur during HSC expansion in in vitro culture. Pot1a levels in HSCs decrease in these processes, but they recover by exogenous POT1a addition and protect from the loss of HSC activity

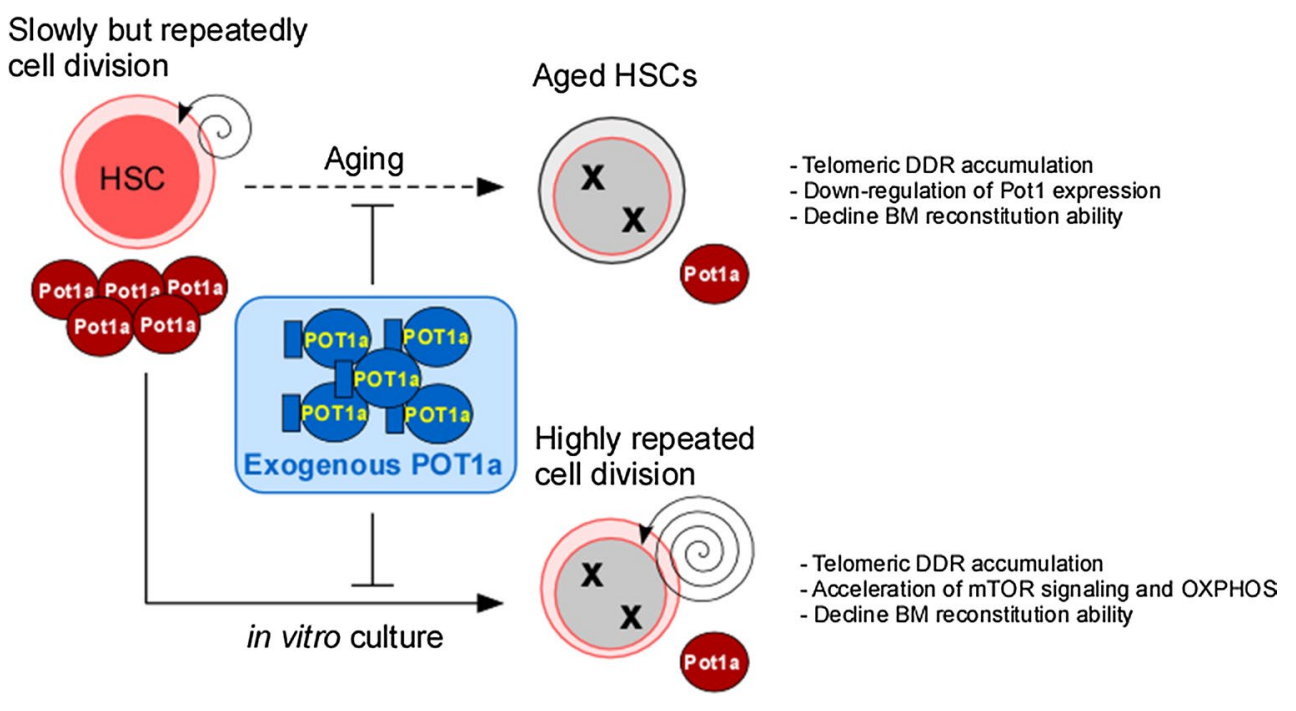

TERT [83]. TIN2 mutations were identified in DC patients [84-86]. Although TIN2 regulates the expression levels of TRF1 and TPP1, the TINF2 mutation found in DC patients reduces the interaction between TIN2 and telomerase without significantly affecting their levels [87]. Also, the HP1 binding site of TIN2 is necessary for sister telomere cohesion in cell division, but this site is located in the DCrelated TINF2 mutation cluster [88]. The TINF2 mutation suppresses the interaction between TIN 2 and HP1 $\gamma$ and may impair the maintenance of telomere length by inhibiting sister telomere cohesion in the telomere region in $\mathrm{S}$ phase [86]. A mouse model with a knock-in mutation in a Tinf2 allele shows a human DC-like phenotype, including mild pancytopenia and telomere shortening [25]. As a result of the mutation of Tinf2, telomeres are broken down and shortened, through a telomerase-independent mechanism. This result may point to the function of Tin2 in sister telomere cohesion in the division phase [86], or to the role played by crosslinking Trf1-Trf2 to regulate telomere compaction and to protect chromosomal ends [89]. In one family affected by HH syndrome, a clinically serious DC mutant, a mutation was found in $A C D$. It was found that there is a one aminoacid deletion in the TEL patch of TPP1 $(\Delta \mathrm{K} 170)$, which is important for promoting recruitment and elongation of telomerase within the OB-fold domain [90]. This mutation has also been found in aplastic anemia and related BMF disorders [78]. Consequently, recruitment of telomerase via the TEL patch on the surface of TPP1 is necessary for proper maintenance of the telomere length of HSCs.

It has been reported that changes in the expression levels of several shelterin components are involved in CLL [72]. Compared with normal lymphocytes, expression of TRF1, RAP1, and POT1 decreased and expression of ACD/TPP1 increased in CLL cells. Telomere dysfunction-induced foci (TIFs), an indicator of telomere defects, increased in
CLL-derived cells [77]. Therefore, telomere instability may be caused in CLL-derived cells. In addition, it was reported that $P O T 1$ somatic mutations occurred in approximately 5\% of CLL cases [91, 92]. In particular, clusters of mutations were observed in the OB-fold domain, which is a DNA binding motif. It has been suggested that POT1 mutation leads to telomere instability and chromosomal abnormality, which is favorable for the acquisition of malignant features of CLL. Overexpression of Y223C, one of the POT1 mutations found in CLL, in hematopoietic cells derived from p53 heterozygotes, promotes the development of transplantable myeloid dysplasia [93]. Furthermore, double deficiency of Pot 1a and p53 in mouse common lymphoid progenitors (CLP) leads to aggressive thymic lymphoma [94]. These findings suggest that tumor formation is suppressed by the ATR-p53 pathway, even if the function of Pot1a declines, but if this pathway is also impaired at the same time, tumorigenesis becomes extremely aggressive.

\section{Conclusions and future directions}

Much progress has been made in the understanding of the maintenance of telomere homeostasis, especially regarding how terminal elongation and end protection are cooperatively regulated. Based on these developments, many causative genetic mutations have been identified in hematological malignancy and human hematopoietic failure syndromes. The genetic mutations found in TINF2, ACD and POT1 impair the function of the normal shelterin complex, leading to failure of proper telomere protection and subsequent chromosomal instability. Clarifying the decline of shelterin function caused by such point mutations is an important theme in clinical research centered on maintaining the integrity of the telomere. The deeper understanding of the maintenance 
Table 2 Mutation and expression abnormalities of shelterin components in the hematopoietic malignancies

\begin{tabular}{|c|c|c|c|c|}
\hline Gene Name & Patient sample/experimental tool & Implications of $\mathrm{s}$ & helterin genes in hematological disease & References\# \\
\hline \multirow[t]{4}{*}{ TRF1 } & Chronic myeloid leukaemia (CML) & & Up-regulation of $T R F 1$ and $T R F 2$ & {$[71]$} \\
\hline & B-chronic lymphocytic leukemia (B-CLL) & & $\begin{array}{l}\text { Down regulation of } T R F 1, R A P 1, P O T 1 \\
\text { Up-regulation of } T P P 1\end{array}$ & {$[72]$} \\
\hline & Acute lymphoblastic leukemia (ALL) & & $\begin{array}{l}\text { Up-regulation of } T R F 1 \text { in patients high hTERT } \\
\text { expression or longer telomere length }\end{array}$ & {$[73]$} \\
\hline & Acute myeloid leukemia (AML) & & $\begin{array}{l}\text { Down regulation of } T R F 1, T R F 2, T I N 2 \text { than } \\
\text { normal cells }\end{array}$ & {$[74]$} \\
\hline \multirow[t]{3}{*}{ TRF2 } & Chronic myeloid leukaemia (CML) & & Up-regulation of $T R F 1$ and $T R F 2$ & {$[71]$} \\
\hline & B-cell acute lymphoblastic leukemia (B-ALL) & & Up-regulation of $T R F 2$ & {$[75]$} \\
\hline & Acute myeloid leukemia (AML) & & $\begin{array}{l}\text { Down regulation of } T R F 1, T R F 2, T I N 2 \text { than } \\
\text { normal cells }\end{array}$ & {$[74]$} \\
\hline $\operatorname{Trf} 2$ & $\begin{array}{l}\text { TRF2 overexpressing hematopoietic precursor } \\
\text { cells }\end{array}$ & & Rarely development of T-cell lymphomas & {$[76]$} \\
\hline \multirow[t]{2}{*}{ RAP1 } & T-cell acute lymphoblastic leukemia (T-ALL) & & Up-regulation of $R A P 1$ & {$[75]$} \\
\hline & B-chronic lymphocytic leukemia (B-CLL) & & $\begin{array}{l}\text { Down regulation of } T R F 1, R A P 1, P O T 1 \\
\text { Up-regulation of } T P P 1\end{array}$ & {$[72]$} \\
\hline \multirow[t]{5}{*}{ TIN2 } & Acute myeloid leukemia (AML) & & $\begin{array}{l}\text { Down regulation of } T R F 1, T R F 2, T I N 2 \text { than } \\
\text { normal cells }\end{array}$ & {$[74]$} \\
\hline & Dyskeratosis congenita (DC) & & $\begin{array}{l}\text { TIN2-encoding gene mutation at } \mathrm{R} 282 \mathrm{H}, \mathrm{R} 282 \mathrm{~S} \\
\text { or K280E }\end{array}$ & {$[84]$} \\
\hline & Dyskeratosis congenita (DC) & & $\begin{array}{l}\text { TIN2-encoding gene mutation at R282H or } \\
\text { R282C }\end{array}$ & {$[85]$} \\
\hline & Dyskeratosis congenita (DC) & & $\begin{array}{l}\text { TIN2-encoding gene mutation at heterochroma- } \\
\text { tin protein } 1 \gamma(\mathrm{HP} 1 \gamma) \text { binding region }\end{array}$ & {$[86]$} \\
\hline & B-chronic lymphocytic leukemia (B-CLL) & & Down regulation of $T I N 2, T P P 1$ & {$[77]$} \\
\hline \multirow[t]{3}{*}{ Tin2 } & \multirow{2}{*}{$\begin{array}{l}\operatorname{Tin} 2(+/ \mathrm{DC} \text { flox); CMV-Cre+ } \\
\text { (conditional mutation induction mice) }\end{array}$} & BM cells & Telomere shortening & {$[25]$} \\
\hline & & $\operatorname{Tin} 2(\mathrm{DC} /+) \mathrm{G} 3$ & $\begin{array}{l}\text { Mild pancytopenia } \\
\text { Hematopoietic dysfunction like dyskeratosis } \\
\text { congenita }\end{array}$ & \\
\hline & $\operatorname{Tin} 2(+/ \mathrm{DC}) ; m T R(-/-)(\mathrm{mTR}: \mathrm{TERC})$ & BM cells & Telomere shortening & {$[25]$} \\
\hline \multirow[t]{4}{*}{ TPP1/ACD } & Hoyeraal-Hreidarsson syndrome $(\mathrm{HH})$ & & $\begin{array}{l}A C D \text {-encoding gene mutation } \mathrm{K} 170 \Delta \text { in TEL } \\
\text { patch region } \\
\text { Fail to recruit telomerase to telomeres }\end{array}$ & {$[90]$} \\
\hline & Aplastic anemia & & $\begin{array}{l}A C D \text {-encoding gene mutation } \mathrm{K} 170 \Delta \text { in TEL } \\
\text { patch region } \\
\text { Fail to recruit telomerase to telomeres }\end{array}$ & {$[78]$} \\
\hline & B-chronic lymphocytic leukemia (B-CLL) & & Down regulation of TIN2, TPP1 & {$[77]$} \\
\hline & B-chronic lymphocytic leukemia (B-CLL) & & $\begin{array}{l}\text { Down regulation of } T R F 1, R A P 1, P O T 1 \\
\text { Up-regulation of } T P P 1\end{array}$ & {$[72]$} \\
\hline \multirow[t]{6}{*}{ POT1 } & Aplastic anemia & & $\begin{array}{l}\text { Downregulation of } P O T 1 \text { expression } \\
\text { No difference in } T R F 1, T R F 2, T I N 2, T P P 1 \text {, and } \\
\text { RAP1 } \\
\text { Activation of ATR signaling }\end{array}$ & {$[79]$} \\
\hline & B-chronic lymphocytic leukemia (B-CLL) & & $\begin{array}{l}\text { Down regulation of } T R F 1, R A P 1, P O T 1 \\
\text { Up-regulation of } T P P 1\end{array}$ & {$[72]$} \\
\hline & Chronic lymphocytic leukemia (CLL) & & $\begin{array}{l}\text { POT1-encoding gene mutation M1L Y36N } \\
\text { Y66X K90Q Q94R Y223C S250X H266L } \\
\text { G272V and C591W }\end{array}$ & {$[91][92]$} \\
\hline & Multiple myeloma (MM) & & Increase the expression of $P O T 1$ & {$[80]$} \\
\hline & $\begin{array}{l}\text { human } P O T 1 \text { Y } 223 \mathrm{C} \text { overexpression in } \\
p 53(-/+) \text { fetal liver hematopoietic cells }\end{array}$ & & $\begin{array}{l}\text { Transplantable myeloid dysplasia } \\
\text { Chromosomal fusion }\end{array}$ & {$[93]$} \\
\hline & Cutaneous T cell lymphoma (CTCL) & & $\begin{array}{l}\text { POT1-encoding gene mutation F62I, F62V, } \\
\text { K90E and R232X in OB-fold domain }\end{array}$ & [94] \\
\hline
\end{tabular}


Table 2 (continued)

\begin{tabular}{llll}
\hline Gene Name & Patient sample/experimental tool & Implications of shelterin genes in hematological disease & References\# \\
\hline Pot1a & Pot1a(flox/flox); p53(flox/flox); $h C D 2-$ Cre & & Thymic lymphoma \\
& & CLP & Chromosomal fusion \\
\hline
\end{tabular}

of telomere integrity will also lead to the development of ex vivo expansion strategies for HSCs. On the other hand, it is also necessary to understand the extra-telomeric functions of shelterin molecules, which are now being uncovered. For example, Tin2 is involved in the control of metabolic activities. Rap1 shows transcriptional activity in the sub-telomeric and non-telomeric regions. In addition, Pot1 may be involved in both transcriptional regulation and metabolic control in HSPCs. In the future, clarifying the molecular function of shelterin proteins in both telomeric and extra-telomeric roles may be particularly beneficial for the full understanding of hematopoietic homeostasis and hematopoietic disorders.

Acknowledgements This work was supported by the funding program for Next Generation World-Leading Researchers (NEXT Program) (LS108), a Scientific Research (B) (General) (26293228), a grant-inaid for Young Scientists (A) (24689041) and a Challenging Exploratory Research (25670453) from the Ministry of Education, Culture, Sports, Science and Technology (MEXT) of Japan, Tokyo Biochemical Research funding, a research grant from the Astellas Foundation for Research on Metabolic Disorders, The Sumitomo Foundation, SENSHIN Medical Research Foundation, Daiichi Sankyo Foundation of Life Science and the European Union's Seventh Framework Programme (FP7/2007-2013) under Grant agreement no: 306240 (SyStemAge). We would like to thank Editage (http://www.editage.jp) for English language editing.

\section{Compliance with ethical standards}

Conflict of interest The author has nothing to disclose.

\section{References}

1. Nijnik A, Woodbine L, Marchetti C, Dawson S, Lambe T, Liu C, et al. DNA repair is limiting for haematopoietic stem cells during ageing. Nature. 2007;447:686-90.

2. Rossi DJ, Bryder D, Seita J, Nussenzweig A, Hoeijmakers J, Weissman IL. Deficiencies in DNA damage repair limit the function of haematopoietic stem cells with age. Nature. 2007;447:725-9.

3. Sperka T, Wang J, Rudolph KL. DNA damage checkpoints in stem cells, ageing and cancer. Nat Rev Mol Cell Biol. 2012;13:579-90.

4. Wang J, Sun Q, Morita Y, Jiang H, Groß A, Lechel A, et al. A differentiation checkpoint limits hematopoietic stem cell self-renewal in response to DNA damage. Cell. 2014;158:1444.

5. Flach J, Bakker ST, Mohrin M, Conroy PC, Pietras EM, Reynaud $\mathrm{D}$, et al. Replication stress is a potent driver of functional decline in ageing haematopoietic stem cells. Nature. 2014;512:198-202.

6. Walter D, Lier A, Geiselhart A, Thalheimer FB, Huntscha S, Sobotta MC, et al. Exit from dormancy provokes
DNA-damage-induced attrition in haematopoietic stem cells. Nature. 2015;520:549-52.

7. Rimmelé P, Liang R, Bigarella CL, Kocabas F, Xie J, Serasinghe $\mathrm{MN}$, et al. Mitochondrial metabolism in hematopoietic stem cells requires functional FOXO3. EMBO Rep. 2015;16:1164-76.

8. Alvarez S, Díaz M, Flach J, Rodriguez-Acebes S, López-Contreras AJ, Martínez D, et al. Replication stress caused by low MCM expression limits fetal erythropoiesis and hematopoietic stem cell functionality. Nat Commun. 2015;6:8548.

9. Shi W, Vu T, Boucher D, Biernacka A, Nde J, Pandita RK, et al. Ssb1 and Ssb2 cooperate to regulate mouse hematopoietic stem and progenitor cells by resolving replicative stress. Blood. 2017;129:2479-92.

10. Szalai VA, Singer MJ, Thorp HH. Site-specific probing of oxidative reactivity and telomerase function using 7,8-dihydro-8-oxoguanine in telomeric DNA. J Am Chem Soc. 2002;124:1625-31.

11. Gong Y, de Lange T. A Shld1-controlled POT1a provides support for repression of ATR signaling at telomeres through RPA exclusion. Mol Cell. 2010;40:377-87.

12. Ray S, Bandaria JN, Qureshi MH, Yildiz A, Balci H. G-quadruplex formation in telomeres enhances POT1/TPP1 protection against RPA binding. Proc Natl Acad Sci. 2014;111:2990-5.

13. de Lange T. How telomeres solve the end-protection problem. Science. 2009;326:948-52.

14. Hosokawa K, MacArthur BD, Ikushima YM, Toyama H, Masuhiro Y, Hanazawa S, et al. The telomere binding protein Pot1 maintains haematopoietic stem cell activity with age. Nat Commun. 2017;8:804.

15. Wang J, Lu X, Sakk V, Klein CA, Rudolph KL. Senescence and apoptosis block hematopoietic activation of quiescent hematopoietic stem cells with short telomeres. Blood. 2014;124:3237-40.

16. Jones M, Osawa G, Regal JA, Weinberg DN, Taggart J, Kocak $\mathrm{H}$, et al. Hematopoietic stem cells are acutely sensitive to Acd shelterin gene inactivation. J Clin Investig. 2014;124:353-66.

17. Wang Y, Sharpless N, Chang S. p16INK4a protects against dysfunctional telomere-induced ATR-dependent DNA damage responses. J Clin Investig. 2013;123:4489-501.

18. Beier F, Foronda M, Martinez P, Blasco MA. Conditional TRF1 knockout in the hematopoietic compartment leads to bone marrow failure and recapitulates clinical features of dyskeratosis congenita. Blood. 2012;120:2990-3000.

19. Ju Z, Zhang J, Gao Y, Cheng T. Telomere dysfunction and cell cycle checkpoints in hematopoietic stem cell aging. Int J Hematol. 2011;94:33-43.

20. Wang RC, Smogorzewska A, de Lange T. Homologous recombination generates T-loop-sized deletions at human telomeres. Cell. 2004;119:355-68.

21. Doksani Y, Wu JY, De Lange T, Zhuang X. Super-resolution fluorescence imaging of telomeres reveals TRF2-dependent T-loop formation. Cell. 2013;155:345-56.

22. Takai KK, Kibe T, Donigian JR, Frescas D, de Lange T. Telomere protection by TPP1/POT1 requires tethering to TIN2. Mol Cell. 2011;44:647-59.

23. Frescas D, de Lange T. TRF2-tethered TIN2 Can mediate telomere protection by TPP1/POT1. Mol Cell Biol. 2014;34:1349-62. 
24. Frescas D, de Lange T. Binding of TPP1 protein to TIN2 protein is required for POT1a, b protein-mediated telomere protection. $\mathrm{J}$ Biol Chem. 2014;289:24180-7.

25. Frescas D, de Lange T. A TIN2 dyskeratosis congenita mutation causes telomerase-independent telomere shortening in mice. Genes Dev. 2014;28:153-66.

26. Erdel F, Kratz K, Willcox S, Griffith JD, Greene EC, de Lange T. Telomere recognition and assembly mechanism of mammalian shelterin. Cell Rep. 2017;18:41-53.

27. Wang F, Podell ER, Zaug AJ, Yang Y, Baciu P, Cech TR, et al. The POT1-TPP1 telomere complex is a telomerase processivity factor. Nature. 2007;445:506-10.

28. Xin H, Liu D, Wan M, Safari A, Kim H, Sun W, et al. TPP1 is a homologue of ciliate TEBP- $\beta$ and interacts with POT1 to recruit telomerase. Nature. 2007;445:559-62.

29. Court R, Chapman L, Fairall L, Rhodes D. How the human telomeric proteins TRF1 and TRF2 recognize telomeric DNA: a view from high-resolution crystal structures. EMBO Rep. 2005;6:39-45.

30. Sfeir A, Kosiyatrakul ST, Hockemeyer D, MacRae SL, Karlseder J, Schildkraut CL, et al. Mammalian telomeres resemble fragile sites and require TRF1 for efficient replication. Cell. 2009;138:90-103.

31. van Steensel B, de Lange T. Control of telomere length by the human telomeric protein TRF1. Nature. 1997;385:740-3.

32. Wu Y, Xiao S, Zhu X-D. MRE11-RAD50-NBS1 and ATM function as co-mediators of TRF1 in telomere length control. Nat Struct Mol Biol. 2007; 14:832-40.

33. Kibe T, Zimmermann M, de Lange T. TPP1 blocks an ATRmediated resection mechanism at telomeres. Mol Cell. 2016;61:236-46.

34. Denchi EL, de Lange T. Protection of telomeres through independent control of ATM and ATR by TRF2 and POT1. Nature. 2007;448:1068-71.

35. Celli GB, Denchi EL, de Lange T. Ku70 stimulates fusion of dysfunctional telomeres yet protects chromosome ends from homologous recombination. Nat Cell Biol. 2006;8:885-90.

36. Bae NS, Baumann P. A RAP1/TRF2 complex inhibits nonhomologous end-joining at human telomeric DNA ends. Mol Cell. 2007;26:323-34

37. Sfeir A, Kabir S, van Overbeek M, Celli GB, de Lange T. Loss of Rap1 induces telomere recombination in the absence of NHEJ or a DNA damage signal. Science. 2010;327:1657-61.

38. Rai R, Chen Y, Lei M, Chang S. TRF2-RAP1 is required to protect telomeres from engaging in homologous recombination-mediated deletions and fusions. Nat Commun. 2016;7:10881.

39. Martinez P, Thanasoula M, Carlos AR, Gómez-López G, Tejera AM, Schoeftner S, et al. Mammalian Rap1 controls telomere function and gene expression through binding to telomeric and extratelomeric sites. Nat Cell Biol. 2010;12:768-80.

40. Chen L-Y, Liu D, Songyang Z. Telomere maintenance through spatial control of telomeric proteins. Mol Cell Biol. 2007;27:5898-909.

41. Abreu E, Aritonovska E, Reichenbach P, Cristofari G, Culp B, Terns RM, et al. TIN2-tethered TPP1 recruits human telomerase to telomeres in vivo. Mol Cell Biol. 2010;30:2971-82.

42. Zhong FL, Batista LFZ, Freund A, Pech MF, Venteicher AS, Artandi SE. TPP1 OB-fold domain controls telomere maintenance by recruiting telomerase to chromosome ends. Cell. 2012;150:481-94

43. Dalby AB, Hofr C, Cech TR. Contributions of the TEL-patch amino acid cluster on TPP1 to telomeric DNA synthesis by human telomerase. J Mol Biol. 2015;427:1291-303.

44. Nandakumar J, Bell CF, Weidenfeld I, Zaug AJ, Leinwand LA, Cech TR. The TEL patch of telomere protein TPP1 mediates telomerase recruitment and processivity. Nature. 2012;492:285-9.
45. Schmidt JC, Zaug AJ, Cech TR. Live cell imaging reveals the dynamics of telomerase recruitment to telomeres. Cell. 2016;166(1188-1197):e9.

46. Lei M, Podell ER, Baumann P, Cech TR. DNA self-recognition in the structure of Pot 1 bound to telomeric single-stranded DNA. Nature. 2003;426:198-203.

47. Lei M, Podell ER, Cech TR. Structure of human POT1 bound to telomeric single-stranded DNA provides a model for chromosome end-protection. Nat Struct Mol Biol. 2004;11:1223-9.

48. Flynn RL, Centore RC, O'Sullivan RJ, Rai R, Tse A, Songyang Z, et al. TERRA and hnRNPA1 orchestrate an RPA-to-POT1 switch on telomeric single-stranded DNA. Nature. 2011;471:532-6.

49. Hockemeyer D, Daniels J-P, Takai H, de Lange T. Recent expansion of the telomeric complex in rodents: two distinct POT1 proteins protect mouse telomeres. Cell. 2006;126:63-77.

50. Wu L, Multani AS, He H, Cosme-Blanco W, Deng Y, Deng JM, et al. Pot1 deficiency initiates DNA damage checkpoint activation and aberrant homologous recombination at telomeres. Cell. 2006;126:49-62.

51. He H, Multani AS, Cosme-Blanco W, Tahara H, Ma J, Pathak S, et al. POT1b protects telomeres from end-to-end chromosomal fusions and aberrant homologous recombination. EMBO J. 2006;25:5180-90.

52. Wu P, Takai $\mathrm{H}$, de Lange $\mathrm{T}$. Telomeric $3^{\prime}$ overhangs derive from resection by Exo1 and apollo and fill-in by POT1b-associated CST. Cell. 2012;150:39-52.

53. Guo X, Deng Y, Lin Y, Cosme-Blanco W, Chan S, He H, et al Dysfunctional telomeres activate an ATM-ATR-dependent DNA damage response to suppress tumorigenesis. EMBO J. 2007;26:4709-19.

54. He H, Wang Y, Guo X, Ramchandani S, Ma J, Shen M-F, et al. Pot $1 \mathrm{~b}$ deletion and telomerase haploinsufficiency in mice initiate an ATR-dependent DNA damage response and elicit phenotypes resembling dyskeratosis congenita. Mol Cell Biol. 2009;29:229-40.

55. El Maï M, Wagner K-D, Michiels J-F, Ambrosetti D, Borderie A, Destree $\mathrm{S}$, et al. The telomeric protein TRF2 regulates angiogenesis by binding and activating the PDGFR $\beta$ promoter. Cell Rep. 2014;9:1047-60.

56. Diala I, Wagner N, Magdinier F, Shkreli M, Sirakov M, Bauwens $\mathrm{S}$, et al. Telomere protection and TRF2 expression are enhanced by the canonical Wnt signalling pathway. EMBO Rep. 2013;14:356-63.

57. Martínez P, Gómez-López G, García F, Mercken E, Mitchell S, Flores JM, et al. RAP1 protects from obesity through its extratelomeric role regulating gene expression. Cell Rep. 2013;3:2059-74

58. Teo H, Ghosh S, Luesch H, Ghosh A, Wong ET, Malik N, et al. Telomere-independent Rap1 is an IKK adaptor and regulates NF- $\mathrm{\kappa B}$-dependent gene expression. Nat Cell Biol. 2010;12:758-67.

59. Chen L-Y, Zhang Y, Zhang Q, Li H, Luo Z, Fang H, et al. Mitochondrial localization of telomeric protein TIN2 links telomere regulation to metabolic control. Mol Cell. 2012;47:839-50.

60. Martinez P, Thanasoula M, Munoz P, Liao C, Tejera A, McNees $\mathrm{C}$, et al. Increased telomere fragility and fusions resulting from TRF1 deficiency lead to degenerative pathologies and increased cancer in mice. Genes Dev. 2009;23:2060-75.

61. Bär C, Povedano JM, Serrano R, Benitez-Buelga C, Popkes M, Formentini I, et al. Telomerase gene therapy rescues telomere length, bone marrow aplasia, and survival in mice with aplastic anemia. Blood. 2016;127:1770-9.

62. Kibe T, Osawa GA, Keegan CE, de Lange T. Telomere protection by TPP1 is mediated by POT1a and POT1b. Mol Cell Biol. 2010;30:1059-66. 
63. Keegan CE, Hutz JE, Else T, Adamska M, Shah SP, Kent AE, et al. Urogenital and caudal dysgenesis in adrenocortical dysplasia (Acd) mice is caused by a splicing mutation in a novel telomeric regulator. Hum Mol Genet. 2005; 14:113-23.

64. Hockemeyer D, Palm W, Wang RC, Couto SS, de Lange T. Engineered telomere degradation models dyskeratosis congenita. Genes Dev. 2008;22:1773-85.

65. Wang Y, Shen M-F, Chang S. Essential roles for Pot1b in HSC self-renewal and survival. Blood. 2011;118:6068-77.

66. Janzen V, Forkert R, Fleming HE, Saito Y, Waring MT, Dombkowski DM, et al. Stem-cell ageing modified by the cyclindependent kinase inhibitor p16INK4a. Nature. 2006;443:421-6.

67. Molofsky AV, Slutsky SG, Joseph NM, He S, Pardal R, Krishnamurthy J, et al. Increasing p16 INK4a expression decreases forebrain progenitors and neurogenesis during ageing. Nature. 2006;443:448-52.

68. Wang Y, Wang X, Flores ER, Yu J, Chang S. Dysfunctional telomeres induce p53-dependent and independent apoptosis to compromise cellular proliferation and inhibit tumor formation. Aging Cell. 2016;15:646-60.

69. Choi KH, Lakamp-Hawley AS, Kolar C, Yan Y, Borgstahl GEO, Ouellette MM. The OB-fold domain 1 of human POT1 recognizes both telomeric and non-telomeric DNA motifs. Biochimie. 2015;115:17-27.

70. Cesare AJ, Hayashi MT, Crabbe L, Karlseder J. The telomere deprotection response is functionally distinct from the genomic DNA damage response. Mol Cell. 2013;51:141-55.

71. Campbell LJ, Fidler C, Eagleton H, Peniket A, Kusec R, Gal S, et al. hTERT, the catalytic component of telomerase, is downregulated in the haematopoietic stem cells of patients with chronic myeloid leukaemia. Leukemia. 2006;20:671-9.

72. Poncet D, Belleville A, de t'Kint Roodenbeke CTK, de Climens AR, Ben Simon E, Merle-Beral H, et al. Changes in the expression of telomere maintenance genes suggest global telomere dysfunction in B-chronic lymphocytic leukemia. Blood. 2008;111:2388-91.

73. Ohyashiki JH, Hayashi S, Yahata N, Iwama H, Ando K, Tauchi $\mathrm{T}$, et al. Impaired telomere regulation mechanism by TRF1 (telomere-binding protein), but not TRF2 expression, in acute leukemia cells. Int J Oncol. 2001;18:593-8.

74. Yamada K, Yagihashi A, Yamada M, Asanuma K, Moriai R, Kobayashi D, et al. Decreased gene expression for telomeric-repeat binding factors and TIN2 in malignant hematopoietic cells. Anticancer Res. 2002;22:1315-20.

75. Capraro V, Zane L, Poncet D, Perol D, Galia P, Preudhomme $\mathrm{C}$, et al. Telomere deregulations possess cytogenetic, phenotype, and prognostic specificities in acute leukemias. Exp Hematol. 2011;39(195-202):e2.

76. Begemann S, Galimi F, Karlseder J. Moderate expression of TRF2 in the hematopoietic system increases development of large cell blastic T-cell lymphomas. Aging (Albany NY). 2009;1:122-30.

77. Augereau A, de t'Kint Roodenbeke C, Simonet T, Bauwens S, Horard B, Callanan M, et al. Telomeric damage in early stage of chronic lymphocytic leukemia correlates with shelterin dysregulation. Blood. 2011;118:1316-22.

78. Guo Y, Kartawinata M, Li J, Pickett HA, Teo J, Kilo T, et al. Inherited bone marrow failure associated with germline mutation of ACD, the gene encoding telomere protein TPP1. Blood. 2014;124:2767-74.

79. Wang T, Mei SC, Fu R, Wang HQ, Shao ZH. Expression of Shelterin component POT1 is associated with decreased telomere length and immunity condition in humans with severe aplastic anemia. J Immunol Res. 2014;2014:439530.

80. Panero J, Stanganelli C, Arbelbide J, Fantl DB, Kohan D, Rivello $\mathrm{HG}$, et al. Expression profile of shelterin components in plasma cell disorders. Clinical significance of POT1 overexpression. Blood Cells Mol Dis. 2014;52:134-9.

81. Mason PJ, Bessler M. The genetics of dyskeratosis congenita. Cancer Genet. 2011;204:635-45.

82. Glousker G, Touzot F, Revy P, Tzfati Y, Savage SA. Unraveling the pathogenesis of Hoyeraal-Hreidarsson syndrome, a complex telomere biology disorder. Br J Haematol. 2015;170:457-71.

83. Savage SA, Bertuch AA. The genetics and clinical manifestations of telomere biology disorders. Genet Med. 2010;12:753-64.

84. Savage SA, Giri N, Baerlocher GM, Orr N, Lansdorp PM, Alter BP. TINF2, a component of the shelterin telomere protection complex, is mutated in dyskeratosis congenita. Am J Hum Genet. 2008;82:501-9.

85. Walne AJ, Vulliamy T, Beswick R, Kirwan M, Dokal I. TINF2 mutations result in very short telomeres: analysis of a large cohort of patients with dyskeratosis congenita and related bone marrow failure syndromes. Blood. 2008;112:3594-600.

86. Canudas S, Houghtaling BR, Bhanot M, Sasa G, Savage SA, Bertuch AA, et al. A role for heterochromatin protein $1 \gamma$ at human telomeres. Genes Dev. 2011;25:1807-19.

87. Frank AK, Tran DC, Qu RW, Stohr BA, Segal DJ, Xu L. The shelterin TIN2 subunit mediates recruitment of telomerase to telomeres. PLoS Genet. 2015;11:e1005410.

88. Canudas S, Smith S. Differential regulation of telomere and centromere cohesion by the Scc3 homologues SA1 and SA2, respectively, in human cells. J Cell Biol. 2009;187:165-73.

89. Bandaria JN, Qin P, Berk V, Chu S, Yildiz A. Shelterin protects chromosome ends by compacting telomeric chromatin. Cell. 2016;164:735-46.

90. Kocak H, Ballew BJ, Bisht K, Eggebeen R, Hicks BD, Suman $\mathrm{S}$, et al. Hoyeraal-Hreidarsson syndrome caused by a germline mutation in the TEL patch of the telomere protein TPP1. Genes Dev. 2014;28:2090-102.

91. Quesada V, Conde L, Villamor N, Ordóñez GR, Jares P, Bassaganyas $\mathrm{L}$, et al. Exome sequencing identifies recurrent mutations of the splicing factor SF3B1 gene in chronic lymphocytic leukemia. Nat Genet. 2012;44:47-52.

92. Ramsay AJ, Quesada V, Foronda M, Conde L, Martínez-Trillos A, Villamor N, et al. POT1 mutations cause telomere dysfunction in chronic lymphocytic leukemia. Nat Genet. 2013;45:526-30.

93. Gu P, Wang Y, Bisht KK, Wu L, Kukova L, Smith EM, et al. Pot1 OB-fold mutations unleash telomere instability to initiate tumorigenesis. Oncogene. 2017;36:1939-51.

94. Tumorigenesis IA, Pinzaru AM, Hom RA, Beal A, Wuttke DS, Pinzaru AM, et al. Telomere replication stress induced by POT1 article telomere replication stress induced by POT1 inactivation accelerates tumorigenesis. Cell Rep. 2016;15:2170-84. 